Historic, Archive Document

Do not assume content reflects current scientific knowledge, policies, or practices. 



\section{BUDDED PECAN TREES} Pecan Grove Farm Nursery and Orchard

J. B. WIGHT, Proprietor CAIRO, GEORGIA

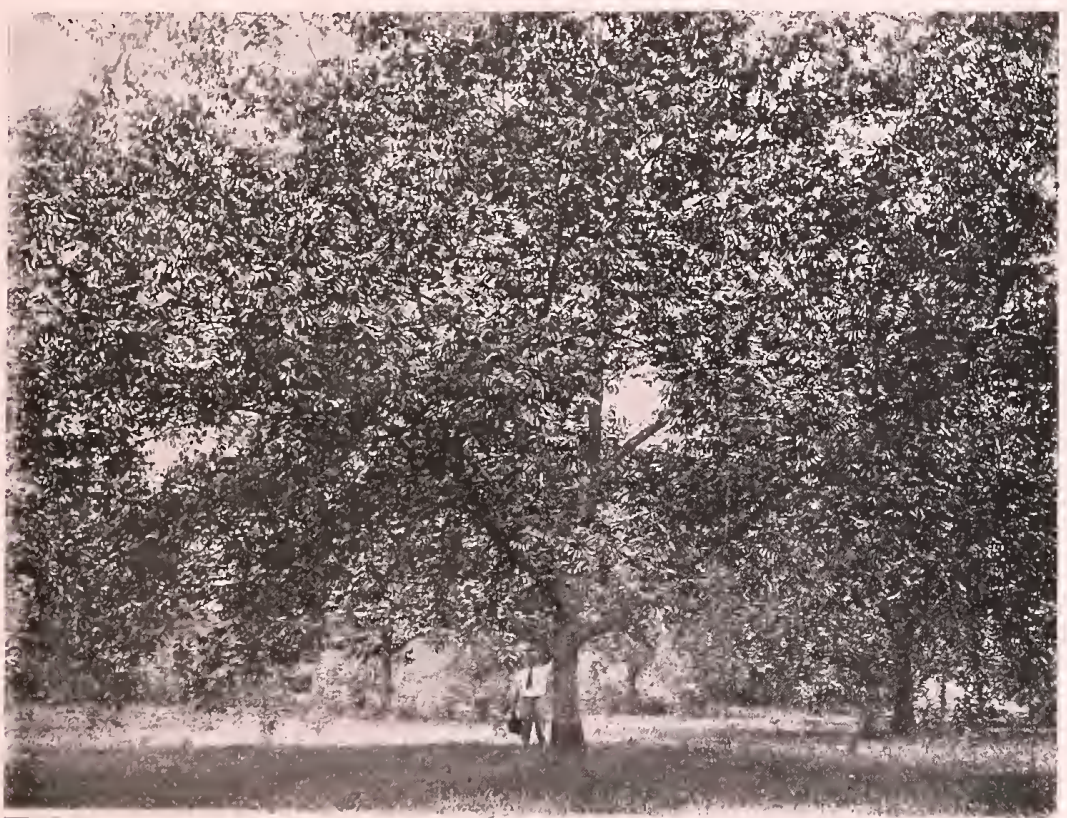

PRICE LIST

SEASON

1917-1918 


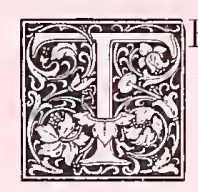

HIRTY years' experience with the pecan has convinced me more and more of its profitableness. The demand for the best nuts is constantly increasing. the producing their crops of nuts to the delight both of the palate and pocketbooks of their owners. A grove once established, a pound of pecans can be grown more cheaply than a pound of cotton; and the grower has twelve months of the year in which to sell them, and the world for his market.

But if success is to come to the pecan grower, there are certain precautions that must be observed: (1) Strong and vigorous budded trees should be set of such varieties as are adapted to the section where they are to be grown. Avoid stunted trees, for a runt in the nursery will remain a dwarf in the grove. (2) Set trees only on the best land. (3) Cultivate, fertilize and care for them in the best manner. These are the three most important requisites to successful pecan growing either on a small or large scale. Observe them and you will not be disappointed.

\section{FACTS AND CONDITIONS OF SALE}

Great care is taken to send out only strong and vigorous trees, which are true to name.

My scions are taken from my own trees, which may be seen growing and fruiting in my groves.

Only strong and vigorous stocks are used for propagating purposes.

I have no agents but my bearing trees, my nursery stock, and my former customers. They speak for themselves.

A cordial invitation is extended to visit my nursery and orchard of 200 acres located near Cairo. To see is to learn.

Cash should accompany all orders, or satisfactory references be given.

No trees held later than December 15th, unless twentyfive per cent. of the price is paid before that date. This is necessary as an evidence of good faith. 
All orders are accepted subject to weather and other conditions beyond my control.

My experience is at the command of those who wish advice as to the best varieties to set in any particular section.

"Anybody can cut prices, but it takes brains to make a better article." This applies to pecan trees: and I supply the better article.

The prices given below are for strong, well rooted trees. carefully packed and delivered to the express or railroad company at Cairo. But express or freight will be prepaid on cash with order for twenty-five or more trees shipped at one time to one person at the following prices:

PRICES

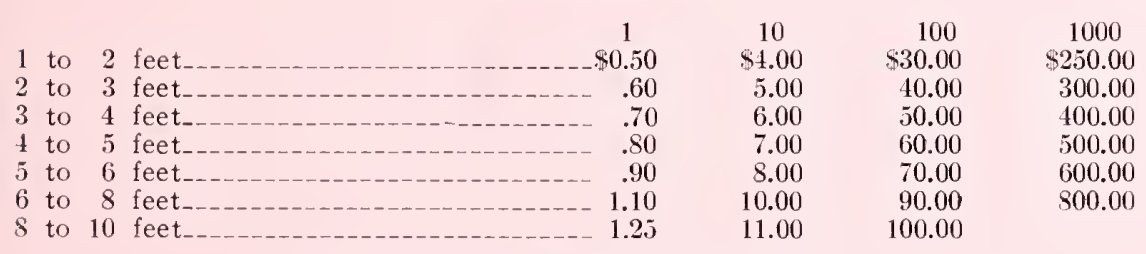

5 trees go at 10 rates, 50 at 100 rates, etc.

\section{VARIETIES}

I am testing about forty of the most promising varieties of pecans. The following I consider among the best of these:

Stuart is an old favorite that has been widlely tested. This is a safe variety to plant, and succeeds over a wider territory than probably any other variety.

Schley is placed by some at the head of the list. It is a large, thin-shelled nut of fine flavor, and is well filled with meat.

Frotscher is a large, thin-shelled nut, which has been widely planted.

Van Deman has also been extensively disseminated, and with many growers it stands at or near the head of the list. 
Success is a new candidate for favor. Originating in Mississippi, it has been widely disseminated during the last six years.

Delmas is a large nut and a very early and prolific bearer.

Pabst is a safe nut; and while not quite so large as some of the above, yet it is a good bearer, and one can hardly make a mistake in setting it.

Nelson is another candiclate for favor. The nut is very large. It is a strong, vigorous grower, and an early and prolific bearer.

Moneymaker is growing in favor. It is an early bearer. prolific, healthy, and in every way is promising.

Can also furnish Moore, Teche, Mobile, Curtis, Alley, and President in limited quantities.

If in doubt as to the best varieties to set, this, when left to me, will receive my most careful attention, thus insuring a better selection than an inexperienced grower could make for himself.

The Nut Grower, published monthly at Waycross, Ga., is the official organ of the National Nut Growers Association. No pecan grower can afford to miss the practical information it contains. That my customers may get the benefit of this publication, I send when requested, the paper free for one year to each one who purchases nursery stock to the amount of $\$ 10.00$ or more.

I have a few "Rush" English walnuts budded on black wal nut stock. These are promising. Price $\$ 1.00$ each.

Address all orders and communications to

$$
\text { J. B. WIGHT, Cairo, Georgia. }
$$

